\title{
A DESCRIPTIVE ANALYSIS OF DECISION SUPPORT SYSTEMS RESEARCH BETWEEN 1990 AND 2003
}

\author{
David Arnott** \\ Graham Pervan \\ Gemma Dodson* \\ *Faculty of Information Technology \\ Monash University \\ Victoria 3800, Australia \\ Email: david.arnott@infotech.monash.edu.au \\ Email: gemma.dodson@infotech.monash.edu.au \\ \# School of Information Systems \\ Curtin University of Technology \\ GPO Box 1987, Perth 6845, Australia \\ Email: pervang@cbs.curtin.edu.au \\ + Corresponding author
}

\begin{abstract}
This paper is the first major report of a project that is investigating the theoretic foundations of decision support systems (DSS). The project was principally motivated by a concern for the direction and relevance of DSS research. The main areas of research focus are the decision and judgement theoretic base of the discipline, the research strategies used in published articles, and the professional relevance of DSS research. The project has analysed 926 DSS articles published in 14 major journals from 1990 to 2003. The findings indicate that DSS research is more dominated by positivist research than general information systems (in particular experiments, surveys, and descriptions of specific applications and systems), is heavily influenced by the work of Herbert Simon, is poorly grounded in contemporary judgement and decision-making research, and falls down in the identification of the nature of clients and users. Of great concern is the finding that DSS research has relatively low professional relevance. An overview of the direction of further analysis is presented.
\end{abstract}

Keywords Decision support systems, group support systems, executive information systems, data warehousing, business intelligence, research, theory.

\section{INTRODUCTION}

Decision support systems (DSS) is the area of the information systems discipline that is focused on supporting and improving managerial decision-making. In terms of contemporary professional practice, DSS includes personal decision support systems, group support systems, executive information systems, online analytical processing systems, data warehousing, and business intelligence.

This project was principally motivated by a concern for the direction and relevance of DSS research. We suspected that research in decision support was increasingly being distanced from professional practice. We also felt that DSS research was addressing an overly narrow range of concepts and issues and in particular we were concerned about the decision theoretic foundation of the area. Further, it seemed that unlike the general trend in information systems research, DSS was strongly dominated by a positivist, quantitative research orthodoxy. To explore these concerns we initiated the project described here. Arnott, Pervan, O'Donnell and Dodson (2004) provided some preliminary results for the project based on the analysis of 380 papers. Since that report we have changed the sample to remove non-academic industry publications and have added articles from 2003 to the sample. As a result this paper presents the first major report of the project. It presents descriptive results based on the analysis of 926 papers. 
The paper is structured as follows: first, the background and rationale of the project is presented. The research methodology and design is then defined. The following sections discuss the results in terms of general research approaches, DSS specific factors, and judgement and decision-making. Finally, some concluding comments are made and the future directions of the project are described.

\section{BACKGROUND AND RATIONALE}

A number of information systems researchers are concerned that there is a widening gap between research and practice, particularly in the systems development area (Galliers, 1994; Saunders, 1998). Fitzgerald (2000) argues that most current systems development methodologies are based on concepts developed in the period 1967 to 1977 . He also argues that changes in the organisational and technical environment since that period have been so great that these methodologies need fundamental review and believes that professional practice is currently leading theory in the development methodology area. This has usually been the case but the divergence is probably greater now than at any other time. Benbasat and Zmud (1999) identified five reasons why information systems research lacks relevance. The first is an emphasis of rigor over relevance in order to gain the respect of other academic disciplines; the second is the lack of a cumulative tradition that yields strong theoretical models that act as a foundation for practical prescription; the third is the dynamism of information technology, which means that practice inevitably leads theory; the fourth is a lack of exposure of IS academics to professional practice; and the fifth is the institutional and political structure of universities which limits the scope of action of IS academics. DSS research, as part of IS research, is likely to be subject to all five forces.

As mentioned in the Introduction, one of the triggers of this project was the perception that the judgement and decision-making foundations of DSS research are relatively narrow. In particular, where judgement is addressed explicitly in DSS research, Simon's process model seems ubiquitous. Simon's model of decision-making (Simon, 1956; 1977) has been used in DSS research since the field's inception and was an integral component of Gorry and Scott Morton's seminal MIS/DSS framework (Gorry \& Scott Morton, 1971). Simon won the Nobel Prize for Economics in 1978 for his theory and as a result it is extremely influential in many social sciences. His model remains the most cited instance of the phase theorem of decision-making. However, in psychological research grave doubts have been expressed about both the descriptive and prescriptive validity of the phase theorem (Lipshitz \& Bar-Ilan, 1996). In management research the descriptive and prescriptive validity of Simon's theory has been repeatedly disconfirmed (Witte, 1972; Alexander, 1979). There is no convincing empirical evidence for the prescriptive validity of any form of the phase theorem, including Simon's.

These fundamental, and seemingly fatal, problems with a major foundation of DSS theory have not been widely acknowledged, although a small number of researchers have raised concerns. Angehrn and Jelassi (1994, p. 269) went as far as to claim: "Simon's theory has become a serious obstacle for the evolution of DSS theory and practice". Elam et al. (1992) argued for a broadening of the theoretical base of DSS through the incorporation of contemporary behavioural decision-making research via collaborative projects with psychologists, while Alter (1992) argued that research on DSS as a technical object had biased the field and called for a greater attention on managerial work and decision-making processes in DSS research. Alter's call for change was particularly important as he was an influential early researcher in the area.

\section{METHODOLOGY AND DESIGN}

The general research questions that guide this project are: 
1. What strategies and methods are used in DSS research?

2. What is the decision support focus and professional relevance of DSS research?

3. What are the judgement theoretic foundations of DSS research?

To answer these questions this project involves the analysis of relevant published research. This style of research has appeared under a number of descriptions in the information systems literature including 'review and assessment of research' (Robey, Boudreau \& Rose, 2000), 'literature review and analysis' (Alavi \& Leidner, 2001), 'survey' (Malone \& Crowston, 1994), and 'literature analysis,' (Pervan, 1998).

\section{Time Frame}

The time period of published research chosen for this project is 1990 to 2003. The start of this analysis period is marked by two much cited reviews: Eom \& Lee (1990) and Benbasat \& Nault (1990). Both of these reviews cover the DSS field from its inception to the late 1980's. A third review paper focusing on DSS implementation, Alavi and Joachimsthaler (1992), provides a further anchor for the 1990 starting date of our analysis, as does the TIMS/ORSA and National Science Foundation sponsored discipline assessment (Stohr \& Konsynski, 1992). The period 1990 to 2003 also marks an interesting period in the development of the information systems discipline as it seemingly witnessed a significant growth in the use of non-positivist research methods. In industry, the analysis period saw the deployment of several new generations of DSS, especially the large-scale approaches of EIS, data warehousing, and business intelligence. To reflect these generations the sample has been divided into three time periods: 1990 to 1994, 1995 to 1999, and 2000 to 2003.

\section{The Article Sample}

The sample of articles analysed in this project is DSS research published between 1990 and 2003 in 14 journals: Accounting, Management \& Information Technologies/Information \& Organization (I\&O); Decision Sciences (DS); Decision Support Systems (DSS); European Journal of Information Systems (EJIS); Information \& Management (I\&M); Information Systems Journal (ISJ); Information Systems Research (ISR); Journal of Information Technology (JIT); Journal of Management Information Systems (JMIS); Journal of Organisational Computing \& Electronic Commerce (JOC\&EC); Journal of Strategic Information Systems (JSIS); Group Decision \& Negotiation (GD\&N); Management Science (MS); and MIS Quarterly (MISQ).

Previous meta-analyses of information systems research have used a similar sampling approach (Benbasat \& Nault, 1990; Alavi \& Carlson, 1992; Pervan, 1998). Alavi and Carlson (1992) used eight North American journals for their sample. However, Webster and Watson (2002) have criticised the over emphasis on North American journals in review papers. In response we included three top-tier European information systems journals (ISJ, EJIS, JIT) and another (JSIS) which has a strong European connection. An alternative approach is to focus on a small number of influential papers (Alavi \& Joachimsthaler, 1992) or to aim for a comprehensive sample of all published research in the area including journal papers, book chapters, and quality conference papers (Webster $\&$ Watson, 2002). We adopted a large set of journals as a basis of the sample because we believe that this best represents the invisible college of DSS research. The articles were selected electronically by examining key words and titles. The first and second authors performed a manual check of the table of contents of each issue of each journal. In addition, the text of each potential article for analysis was examined to verify its decision support content. The distribution of articles is shown in Table 1. DSS dominates the sample with $35.7 \%$ of articles. The discipline share of $D S$, $D S S$, and JOC\&EC has fallen over time. The latter is probably due to that particular journal's 
declining interest in collaboration technology. The European journals have a surprisingly low DSS publication rate.

Table 1: Sample by Journal

\begin{tabular}{|l|l|l|l|l|l|l|l|l|}
\hline \multirow{3}{*}{ Journal } & $\mathbf{1 9 9 0}-$ & $\mathbf{1 9 9 4}$ & $\mathbf{1 9 9 5}-$ & $\mathbf{1 9 9 9}$ & $\mathbf{2 0 0 0}-\mathbf{2 0 0 3}$ & \multicolumn{2}{|l|}{ Total } \\
\cline { 2 - 9 } & $\begin{array}{l}\text { No of } \\
\text { Articles }\end{array}$ & $\begin{array}{l}\text { \% of } \\
\text { Period }\end{array}$ & $\begin{array}{l}\text { No of } \\
\text { Articles }\end{array}$ & $\begin{array}{l}\text { \% of } \\
\text { Period }\end{array}$ & $\begin{array}{l}\text { No of } \\
\text { Articles }\end{array}$ & $\begin{array}{l}\text { \% of } \\
\text { Period }\end{array}$ & $\begin{array}{l}\text { No of } \\
\text { Articles }\end{array}$ & $\begin{array}{l}\text { \% of } \\
\text { Sample }\end{array}$ \\
\hline I\&O & 5 & 1.4 & 8 & 2.0 & 2 & 1.2 & 15 & 1.6 \\
\hline DS & 32 & 8.9 & 20 & 5.0 & 10 & 5.8 & 62 & 6.7 \\
\hline DSS & 118 & 33.0 & 166 & 41.8 & 47 & 27.5 & 331 & 35.7 \\
\hline EJIS & 9 & 2.5 & 9 & 2.3 & 3 & 1.8 & 21 & 2.3 \\
\hline I\&M & 40 & 11.2 & 31 & 7.8 & 22 & 12.9 & 93 & 10.0 \\
\hline ISJ & 7 & 2.0 & 4 & 1.0 & 3 & 1.8 & 14 & 1.5 \\
\hline ISR & 16 & 4.5 & 11 & 2.8 & 5 & 2.9 & 32 & 3.5 \\
\hline JIT & 14 & 3.9 & 6 & 1.5 & 2 & 1.2 & 22 & 2.4 \\
\hline JMIS & 30 & 8.4 & 34 & 8.6 & 13 & 7.6 & 77 & 8.3 \\
\hline JOC\&EC & 36 & 10.1 & 25 & 6.3 & 8 & 4.7 & 69 & 7.5 \\
\hline JSIS & 2 & 0.6 & 2 & 0.5 & 4 & 2.3 & 8 & 0.9 \\
\hline GD\&N & 13 & 3.6 & 59 & 14.9 & 39 & 22.8 & 111 & 12.0 \\
\hline MS & 18 & 5.0 & 13 & 3.3 & 7 & 4.1 & 38 & 4.1 \\
\hline MISQ & 18 & 5.0 & 9 & 2.3 & 6 & 3.5 & 33 & 3.6 \\
\hline Total & 358 & 100.0 & 397 & 100.0 & 171 & 100.0 & 926 & 100.0 \\
\hline
\end{tabular}

\section{Procedure}

A protocol was used to code each paper. Some papers, termed 'example articles', were selected as being representative of the various article types. To calibrate the coding process the example articles were coded independently by two researchers. The third researcher reviewed all responses. The articles were then coded by the three researchers working independently. In coding each paper the emphasis was on the dominant attribute of each factor for each paper. Any uncertainty in coding was referred to one researcher for adjudication. The coding of citations of judgement and decisionmaking research was also reviewed by one researcher. The coded protocols were entered into an SPSS database for analysis by another researcher. This researcher also performed consistency checks on the coding.

\section{ANALYSIS BY GENERAL RESEARCH FACTORS}

In addressing the first research question (what strategies and methods are used in DSS research?) the general research factors considered were research paradigm, research stage, and article type. These factors are not independent but each is a useful lens for analysis in itself. The period of analysis 1990 to 2003 saw a significant move in general information systems research towards interpretivism (Orlikowski \& Baroudi, 1991; Walsham, 1995b; Cavaye, 1996) and to a lesser extent, critical theory (Hirschheim, 1992). A major consequence of this paradigmatic trend was the rise of the case study as a major research strategy in information systems (Walsham, 1995a). The movement to a more complex and sophisticated disciplinary structure also occurred in social science in general (Guba \& 
Lincoln, 1994). Table 2 shows the empirical papers in the sample coded for paradigm. DSS research is overwhelmingly dominated by the positivist paradigm with $91 \%$ of empirical studies following that approach. Chin and Hirschheim's (2004) study of IS research from 1991 to 2001 reported that $81 \%$ of papers had a positivist orientation with $19 \%$ using an interpretivist approach. This means that DSS research is more dominated by positivism than general IS research. Examination of the temporal trends in Table 2 shows that interpretivism in DSS research is gradually expanding from its low base.

Table 2: Sample by Research Paradigm

\begin{tabular}{|l|l|l|l|l|l|l|l|l|}
\hline \multirow{2}{*}{ Paradigm } & $\mathbf{1 9 9 0}-$ & $\mathbf{1 9 9 4}$ & $\mathbf{1 9 9 5}-$ & $\mathbf{1 9 9 9}$ & $\mathbf{2 0 0 0}-\mathbf{2 0 0 3}$ & \multicolumn{2}{|l|}{ Total } \\
\cline { 2 - 9 } & $\begin{array}{l}\text { No of } \\
\text { Articles }\end{array}$ & $\begin{array}{l}\text { \% of } \\
\text { Period }\end{array}$ & $\begin{array}{l}\text { No of } \\
\text { Articles }\end{array}$ & $\begin{array}{l}\text { \% of } \\
\text { Period }\end{array}$ & $\begin{array}{l}\text { No of } \\
\text { Articles }\end{array}$ & $\begin{array}{l}\text { \% of } \\
\text { Period }\end{array}$ & $\begin{array}{l}\text { No of } \\
\text { Articles }\end{array}$ & $\begin{array}{l}\text { \% of } \\
\text { Sample }\end{array}$ \\
\hline Positivist & 204 & 93.2 & 241 & 92.0 & 113 & 89.0 & 558 & 91.8 \\
\hline Interpretivist & 15 & 6.8 & 20 & 7.6 & 14 & 11.0 & 49 & 8.1 \\
\hline Mixed & 0 & 0.0 & 1 & 0.4 & 0 & 0.0 & 1 & 0.2 \\
\hline Total & 219 & 100.0 & 262 & 100.0 & 127 & 100.0 & 608 & 100.0 \\
\hline
\end{tabular}

Galliers (1992) proposed a framework for understanding research and its interaction with theory by conceptualising the research process as a cycle of theory building, theory testing, and theory refinement. Table 3 shows the sample by the dominant stage in the research cycle. It shows that DSS research is dominated by theory building. On the one hand this is surprising given the life of the area relative to IT in general. Given this longevity it could be expected that theory testing and refinement would now have a much greater focus. In the sample, theory testing has significantly expanded, albeit from a low base. An explanation for the statistics could come from the development of new DSS movements, especially EIS, data warehousing, and business intelligence. Each new movement has required significant theorising and this may keep the theory building percentage of research high in the sample.

Table 3: Sample by Dominant Research Stage

\begin{tabular}{|l|l|l|l|l|l|l|l|l|}
\hline \multirow{2}{*}{ Research Stage } & $\mathbf{1 9 9 0}-$ & $\mathbf{1 9 9 4}$ & $\mathbf{1 9 9 5}-$ & $\mathbf{1 9 9 9}$ & $\mathbf{2 0 0 0}-\mathbf{2 0 0 3}$ & \multicolumn{2}{|l|}{ Total } \\
\cline { 2 - 10 } & $\begin{array}{l}\text { No of } \\
\text { Articles }\end{array}$ & $\begin{array}{l}\text { \% of } \\
\text { Period }\end{array}$ & $\begin{array}{l}\text { No of } \\
\text { Articles }\end{array}$ & $\begin{array}{l}\text { \% of } \\
\text { Period }\end{array}$ & $\begin{array}{l}\text { No of } \\
\text { Articles }\end{array}$ & $\begin{array}{l}\text { \% of } \\
\text { Period }\end{array}$ & $\begin{array}{l}\text { No of } \\
\text { Articles }\end{array}$ & $\begin{array}{l}\text { \% of } \\
\text { Sample }\end{array}$ \\
\hline Theory Building & 251 & 70.1 & 255 & 64.2 & 101 & 59.1 & 607 & 65.6 \\
\hline Theory Testing & 72 & 20.1 & 113 & 28.5 & 58 & 33.9 & 243 & 26.2 \\
\hline Theory Refinement & 13 & 3.6 & 12 & 3.0 & 4 & 2.3 & 29 & 3.1 \\
\hline Unclear & 22 & 6.1 & 17 & 4.3 & 8 & 4.7 & 47 & 5.1 \\
\hline Total & 358 & 100.0 & 397 & 100.0 & 171 & 100.0 & 926 & 100.0 \\
\hline
\end{tabular}

There are a number of different approaches to classifying the type of research in addition to paradigm and stage of research. The approach used in this project is that used by Pervan (1998) in his analysis of published group support systems research. Pervan's taxonomy was based on Alavi and Carlson (1992). The only modification has been to substitute "DSS" for "GSS". The article type taxonomy and the distribution of papers are shown in Table 4. Also provided in the table is an example of each article type.

Table 4 shows that around one-third (32.9\%) of DSS research is non-empirical, with two-thirds 
(67.1\%) empirical. Chin \& Hirschheim's (2004) analysis of overall IS research reported a significantly different split between non-empirical (40\%) and empirical (60\%). DSS research has significantly more empirical research than general IS. The high $17.4 \%$ figure for the category "Description of Specific Application, System etc" and the low combined case study score of 8.4\% are particularly noteworthy.

Table 4. Sample by Article Type

\begin{tabular}{|c|c|c|c|c|}
\hline & Article Trpe & & Number & $\%$ \\
\hline Non- & Conceptual & DSS Frameworks & 41 & 4.4 \\
\hline & & Conceptual Models & 23 & 2.5 \\
\hline & & Conceptual Overview & 45 & 4.9 \\
\hline & & Theory & 20 & 2.2 \\
\hline & Illustrative & Opinion \& Example & 19 & 2.1 \\
\hline & & Oninion \& Personal Exnerience & 4 & 0.4 \\
\hline & & Tools, Techniques, Methods, Model & 91 & 9.8 \\
\hline & Applied Concepts & Conceptual Frameworks \& Their Application & 62 & 6.7 \\
\hline $\begin{array}{l}\text { Empirica } \\
1\end{array}$ & Objects & $\begin{array}{l}\text { Description of Type or Class of Product, } \\
\text { Technology, Systems etc. }\end{array}$ & 29 & 3.1 \\
\hline & & Description of Specific Application, System & 161 & 17.4 \\
\hline & Events/Processes & Lab Experiment & 176 & 19.0 \\
\hline & & Field Experiment & 15 & 1.6 \\
\hline & & Field Study & 33 & 3.6 \\
\hline & & Positivist Case Study & 48 & 5.2 \\
\hline & & Interpretivist Case Study & 30 & 3.2 \\
\hline & & Action Research & 7 & 0.6 \\
\hline & & Survev & 68 & 7.3 \\
\hline & & Development of DSS Instrument & 4 & 0.4 \\
\hline & & Secondary Data & 23 & 2.5 \\
\hline & & Simulation & 27 & 2.9 \\
\hline
\end{tabular}

\section{ANALYSIS BY DSS FACTORS}

In answering the second research question (what is the decision support focus and professional relevance of DSS research?) the DSS factors addressed were DSS type, organisational level of support, decision support focus, and practical relevance. Decision support systems, while addressing the computer-based support of management decision-making, is not a homogenous field in terms of applications. There are a number of different approaches to DSS and each has had a period of popularity in both research and practice (Arnott \& O'Donnell, 1994). One way of classifying a DSS is by the nature of the information systems development. Each of these "DSS types" represents a different philosophy of support, system scale, level of investment, and potential organisational impact.

Personal DSS (PDSS) are small-scale systems that are normally developed for one manager (or a small number of independent managers) for one decision task. PDSS are the oldest form of decision support system (Keen \& Scott Morton, 1978) and include modelling systems and what industry currently terms "analytics". In a PDSS an individual manager has power or responsibility for the decision but in a group support system (GSS) decision responsibility is shared by a number of managers and a number of managers need to be involved in the decision process. GSS are typically implemented as electronic meeting systems (Dennis et al., 1988) or group decision systems (Pervan \& Atkinson, 1995). Negotiation support systems (NSS) also operate in a group context but as the 
name suggests they involve the application of computer technologies to facilitate negotiations (Rangaswamy \& Shell, 1997).

Executive information systems were originally systems that aimed to support senior executives (Rockart \& DeLong, 1988) but quickly spread through all management levels. They are oriented towards reporting aspects of organisational performance using multidimensional databases or OLAP (online analytical processing) technology (Codd, Codd \& Salley, 1993). A data warehouse is a set of databases created to provide information to decision makers (Cooper et al., 2000). There are two fundamental approaches to data warehouses: enterprise level data warehouses (Inmon \& Hackathorn, 1994) and division or department level data marts (Kimball et al. 1998). Data warehouses can also be viewed as an attempt to provide a large-scale infrastructure for decision support in that PDSS and EIS can use data from the data warehouse and data marts.

Artificial intelligence techniques have been applied to decision support and these systems are normally called intelligent DSS or IDSS (Bidgoli, 1998) although the term knowledge-based DSS has also been used (Doukidis, Land, \& Miller,1989). Knowledge management as an information systems movement has also had an impact on DSS research with a major conference on the topic being held in 2000 (Carlsson et al., 2000).

Table 5 shows that the research is mainly focused in three areas: personal DSS, group systems, and large data driven systems (EIS and data warehouses). Personal DSS and intelligent DSS are declining in attention while data warehousing, knowledge management-based DSS, and negotiation support systems are increasing significantly, although data warehousing and knowledge management-based DSS have a very low of exposure in major journals. This may be a factor in the professional relevance findings discussed later.

Table 5: Sample by DSS Type

\begin{tabular}{|l|l|l|l|l|l|l|l|l|}
\hline DSS Type & $\mathbf{1 9 9 0}-\mathbf{1 9 9 4}$ & $\mathbf{1 9 9 5}-\mathbf{1 9 9 9}$ & $\mathbf{2 0 0 0}-\mathbf{2 0 0 3}$ & \multicolumn{2}{|l|}{ Total } \\
\cline { 2 - 10 } & $\begin{array}{l}\text { No of } \\
\text { Articles }\end{array}$ & $\begin{array}{l}\text { \% of } \\
\text { Period }\end{array}$ & $\begin{array}{l}\text { No of } \\
\text { Articles }\end{array}$ & $\begin{array}{l}\text { \% of } \\
\text { Period }\end{array}$ & $\begin{array}{l}\text { No of } \\
\text { Articles }\end{array}$ & $\begin{array}{l}\text { \% of } \\
\text { Period }\end{array}$ & $\begin{array}{l}\text { No of } \\
\text { Articles }\end{array}$ & $\begin{array}{l}\text { \% of } \\
\text { Sample }\end{array}$ \\
\hline $\begin{array}{l}\text { Personal DSS (incl. } \\
\text { analytics) }\end{array}$ & 134 & 37.4 & 135 & 34.0 & 44 & 25.7 & 313 & 33.8 \\
\hline Group Support Systems & 104 & 29.1 & 125 & 31.5 & 55 & 33.9 & 287 & 31.0 \\
\hline $\begin{array}{l}\text { EIS (includes BI \& } \\
\text { OLAP) }\end{array}$ & 27 & 7.5 & 30 & 7.6 & 12 & & 69 & 7.5 \\
\hline Data Warehouse & 0 & 0.0 & 2 & 0.5 & 9 & 5.3 & 11 & 1.2 \\
\hline Intelligent DSS & 58 & 16.2 & 55 & 13.9 & 14 & 8.2 & 127 & 13.7 \\
\hline $\begin{array}{l}\text { Knowledge Mgt based } \\
\text { DSS }\end{array}$ & 3 & 0.8 & 6 & 1.5 & 8 & & 17 & 1.8 \\
\hline $\begin{array}{l}\text { Negotiation Support } \\
\text { Systems }\end{array}$ & 6 & 1.7 & 18 & 4.5 & 17 & & 41 & 4.4 \\
\hline Many & 26 & 7.3 & 26 & 6.5 & 9 & 5.3 & 61 & 6.6 \\
\hline Total & 358 & 100.0 & 397 & 100.0 & 171 & 100.0 & 926 & 100.0 \\
\hline
\end{tabular}

Another way of classifying a DSS is by the unit of analysis of the research. The unit of analysis specifies the focus of the research project and is usually guided by the reference theories and previous domain research used by the researchers. Table 6 shows that the decision support focus of the papers was reasonably spread across system development, information technology, the impact of the systems on the organization, and the decision-making process. Over time researcher focus on 
development and technology has declined and research with a focus on decision outcome and organizational impact has doubled. Intuitively, this mirrors the increasing organizational and social focus of IS research in general.

Table 6: Sample by Decision Support Focus

\begin{tabular}{|c|c|c|c|c|c|c|c|c|}
\hline \multirow{2}{*}{$\begin{array}{l}\text { Decision Support } \\
\text { Focus }\end{array}$} & \multirow{2}{*}{\begin{tabular}{|l|}
1990 - \\
$\begin{array}{l}\text { No of } \\
\text { Articles }\end{array}$
\end{tabular}} & \multirow{2}{*}{\begin{tabular}{|l}
1994 \\
$\begin{array}{l}\text { \% of } \\
\text { Period }\end{array}$
\end{tabular}} & \multirow{2}{*}{\begin{tabular}{|l|}
1995 - \\
$\begin{array}{l}\text { No of } \\
\text { Articles }\end{array}$
\end{tabular}} & \multirow{2}{*}{\begin{tabular}{|l|}
1999 \\
$\begin{array}{l}\text { \% of } \\
\text { Period }\end{array}$
\end{tabular}} & \multirow{2}{*}{\begin{tabular}{|l}
2000 - \\
$\begin{array}{l}\text { No of } \\
\text { Articles }\end{array}$
\end{tabular}} & \multirow{2}{*}{\begin{tabular}{|l|}
2003 \\
$\begin{array}{l}\% \text { of } \\
\text { Period }\end{array}$ \\
\end{tabular}} & \multicolumn{2}{|l|}{ Total } \\
\hline & & & & & & & \begin{tabular}{|l} 
No of \\
Articles
\end{tabular} & \begin{tabular}{|l|}
$\begin{array}{l}\% \\
\text { Sample of } \\
\text { Sample }\end{array}$ \\
\end{tabular} \\
\hline Systems Development & 83 & 23.2 & 87 & 21.9 & 30 & 17.5 & 200 & 21.6 \\
\hline Information Technology & 95 & 26.5 & 96 & 24.2 & 35 & 20.5 & 226 & 24.4 \\
\hline $\begin{array}{l}\text { Decision Outcome/Org } \\
\text { Impact }\end{array}$ & 40 & 11.2 & 68 & 17.1 & 39 & 22.8 & 147 & 15.9 \\
\hline $\begin{array}{l}\text { Decision-making } \\
\text { Process }\end{array}$ & 75 & 20.9 & 71 & 17.9 & 35 & 20.5 & 181 & 19.5 \\
\hline Many & 56 & 15.6 & 69 & 17.4 & 28 & 16.4 & 153 & 16.5 \\
\hline Unclear & 9 & 2.5 & 6 & 1.5 & 4 & 2.3 & 19 & 2.1 \\
\hline Total & 358 & 100.0 & 397 & 100.0 & 171 & 100.0 & 926 & 100.0 \\
\hline
\end{tabular}

The final DSS factor that was analysed was the practical relevance of the research in each article. Any professionally focused academic area (like DSS) needs a reasonable balance between theory development and application since research and practice inform each other (Galliers, 1994). The assessment of practical relevance is a subjective judgement that was informed by the aims and objectives of each paper, the nature of the discussion, and in particular the content of the concluding comments of each paper. The researchers spent considerable time in discussing and reviewing their coding of this factor to assist in calibrating the independent coding processes.

Table 7 shows that overall, only $9.5 \%$ of research is regarded as having high or very high practical relevance. On the other hand, 53.2\% of research was regarded as having no or low practical relevance. Even though the high and very high practical relevance statistics vary over time periods the figures are so low as to constitute a potential crisis in the DSS discipline. While the project was initiated with a concern for the relevance of DSS research we were surprised by the strength of this adverse finding. We believe that all of the factors identified by Benbasat and Zmud (1999) are in play in DSS research. The relative lack of exposure of academics to contemporary professional practice is a particular problem for DSS.

Table 7: Sample by Practical Relevance

\begin{tabular}{|l|l|l|l|l|l|l|l|l|}
\hline Practical Relevance & $\mathbf{1 9 9 0}-$ & $\mathbf{1 9 9 4}$ & $\mathbf{1 9 9 5}-$ & $\mathbf{1 9 9 9}$ & $\mathbf{2 0 0 0}-$ & $\mathbf{2 0 0 3}$ & Total \\
\cline { 2 - 9 } & $\begin{array}{l}\text { No of } \\
\text { Articles }\end{array}$ & $\begin{array}{l}\text { \% of } \\
\text { Period }\end{array}$ & $\begin{array}{l}\text { No of } \\
\text { Articles }\end{array}$ & $\begin{array}{l}\text { \% of } \\
\text { Period }\end{array}$ & $\begin{array}{l}\text { No of } \\
\text { Articles }\end{array}$ & $\begin{array}{l}\text { \% of } \\
\text { Period }\end{array}$ & $\begin{array}{l}\text { No of } \\
\text { Articles }\end{array}$ & $\begin{array}{l}\text { \%of } \\
\text { Sample }\end{array}$ \\
\hline Very High & 3 & 0.8 & 2 & 0.5 & 4 & 2.3 & 9 & 1.0 \\
\hline High & 31 & 8.7 & 22 & 5.5 & 26 & 15.2 & 79 & 8.5 \\
\hline Medium & 121 & 33.8 & 164 & 41.3 & 80 & 35.1 & 345 & 37.3 \\
\hline Low & 178 & 49.7 & 173 & 43.6 & 66 & 38.6 & 417 & 45.0 \\
\hline None & 25 & 7.0 & 36 & 9.1 & 15 & 8.8 & 76 & 8.2 \\
\hline Total & 358 & 100.0 & 397 & 100.0 & 171 & 100.0 & 926 & 100.0 \\
\hline
\end{tabular}




\section{ANALYSIS BY JUDGEMENT \& DECISION-MAKING FOUNDATIONS}

The third focusing research question was: What are the judgement theoretic foundations of DSS research? The first sentence of this paper defined DSS as "the area of the information systems discipline that is focused on supporting and improving managerial decision-making". The managerial nature of DSS seems axiomatic and even one of the first DSS books was titled "Management Support Systems" (McCosh \& Scott Morton, 1978). This project identified the primary clients and users in DSS research by evaluating what organisational role was played, or was assumed to be played, by the primary client and user in each paper. Table 8 shows the results of the application of this classification to the sample. Of note are the very high figures in the unclear category: $88.8 \%$ for the primary client and $57.3 \%$ for the primary user. This lack of identification of the client or sponsor is particularly noteworthy as research has repeatedly found that executive and operational sponsorship are critical success factors for information systems that support managers (Poon \& Wagner, 2001). This lack of identification of primary clients and users is a major shortcoming in DSS scholarship.

Table 8: Sample by Primary Client and Primary User

\begin{tabular}{|l|l|l|l|l|}
\hline & Primarv & Client & Primarv & User \\
\hline & Frequencv & Percentage & Frequencv & Percentage \\
\hline Executive & 52 & 5.6 & 67 & 7.2 \\
\hline Non-Executive Manager & 15 & 1.6 & 83 & 9.0 \\
\hline Professional & 24 & 2.6 & 118 & 12.7 \\
\hline Other Knowledge Worker & 13 & 1.4 & 34 & 3.7 \\
\hline Many & - & - & 93 & 10.0 \\
\hline Unclear & 822 & 88.8 & 531 & 57.3 \\
\hline Total & 926 & & 872 & \\
\hline
\end{tabular}

Each article was examined to see if any reference theory in judgement and decision-making was explicitly used. Surprisingly, $45.8 \%$ of papers did not cite any reference research in judgement and decision-making. Table 9 shows the number of citations to judgement and decision-making reference research for each type of DSS. Group and negotiation support have the most reference citations, with the current professional mainstream of data warehousing having the poorest grounding. As predicted in the Rationale section, of those who cited judgement and decision-making references, the work of Simon was by far the most popular. Another surprising finding was that $79.8 \%$ of DSS research did not use a form of the phase theorem of decision-making in their theoretical foundation.

Table 9: Number of Cited Judgement and Decision-making References by DSS Type

\begin{tabular}{|l|l|l|l|l|}
\hline Type of DSS & $\begin{array}{l}\text { No of } \\
\text { Articles }\end{array}$ & Mean & $\begin{array}{l}\text { Standard } \\
\text { Deviation }\end{array}$ & Median \\
\hline Personal DSS & 313 & 2.28 & 3.87 & 1.00 \\
\hline Group Support Svstems & 287 & 2.69 & 3.22 & 2.00 \\
\hline EIS & 69 & 1.67 & 2.95 & 0.00 \\
\hline Data Warehouse & 11 & 0.00 & 0.00 & 0.00 \\
\hline Intelligent DSS & 127 & 0.81 & 1.73 & 0.00 \\
\hline Knowledge Management Based & 17 & 1.24 & 1.86 & 0.00 \\
\hline Negotiation Support Svstems & 41 & 2.37 & 2.66 & 1.00 \\
\hline Many & 61 & 2.92 & 4.88 & 1.00 \\
\hline Total & 926 & 2.16 & 3.42 & 1.00 \\
\hline
\end{tabular}


The general theoretical approach to decision-making can be classified in many ways. Two of the most common classifications are used in this project, with the first being the difference between descriptive and prescriptive approaches A descriptive approach aims to describe how decisions are made in reality and these theories can be useful for understanding the context of decision support. Prescriptive theories, which are often called normative theories, aim to recommend the best or most appropriate way to make a decision. Some authors use the terms differently and use "prescriptive" for the theory space between purely descriptive and purely normative (Bell, Raiffa, \& Tversky, 1988). We use descriptive and prescriptive as descriptors as they are the most commonly used in DSS research. Both descriptive and prescriptive theories have been important for DSS since the early days of the field (Keen \& Scott Morton, 1978). Table 10 shows that a prescriptive approach dominates DSS research.

Table 10: Sample by Decision-making Approach 1

\begin{tabular}{|l|l|l|l|l|l|l|l|l|}
\hline & $\mathbf{1 9 9 0}-$ & $\mathbf{1 9 9 4}$ & $\mathbf{1 9 9 5}-$ & $\mathbf{1 9 9 9}$ & $\mathbf{2 0 0 0}-$ & $\mathbf{2 0 0 3}$ & Total \\
\cline { 2 - 9 } & $\begin{array}{l}\text { No of } \\
\text { Articles }\end{array}$ & $\begin{array}{l}\mathbf{\%} \text { of } \\
\text { Period }\end{array}$ & $\begin{array}{l}\text { No of } \\
\text { Articles }\end{array}$ & $\begin{array}{l}\text { \% of } \\
\text { Period }\end{array}$ & $\begin{array}{l}\text { No of } \\
\text { Articles }\end{array}$ & $\begin{array}{l}\text { \% of } \\
\text { Period }\end{array}$ & $\begin{array}{l}\text { No of } \\
\text { Articles }\end{array}$ & $\begin{array}{l}\text { \%o of } \\
\text { Sample }\end{array}$ \\
\hline Descriptive & 90 & 25.1 & 86 & 21.7 & 49 & 28.7 & 225 & 24.3 \\
\hline Prescriptive & 183 & 51.1 & 202 & 50.9 & 79 & 46.2 & 464 & 50.1 \\
\hline Both & 0 & 0.0 & 0 & 0.0 & 1 & 0.6 & 1 & 0.1 \\
\hline Unclear & 85 & 23.7 & 109 & 27.5 & 42 & 24.6 & 236 & 25.6 \\
\hline Total & 358 & 100.0 & 397 & 100.0 & 171 & 100.0 & 926 & 100.0 \\
\hline
\end{tabular}

The second classification of decision-making approach as being economic or behavioural overlaps with the first. Economic approaches are usually aimed at maximising some objective subject to constraints and tend to be prescriptive (Goodwin \& Wright, 1991) while behavioural decision approaches, which come largely from psychology, are usually based on an understanding of actual behaviour (for example, Gigerenzer, 2000). Nevertheless, behavioural approaches can be prescriptive and some economic approaches have descriptive aspects. Table 11 shows that a behavioural approach dominates DSS research. 
Table 11: Sample by Decision-making Approach 2

\begin{tabular}{|l|l|l|l|l|l|l|l|l|}
\hline & $\mathbf{1 9 9 0}-$ & $\mathbf{1 9 9 4}$ & $\mathbf{1 9 9 5}-$ & $\mathbf{1 9 9 9}$ & $\mathbf{2 0 0 0}-$ & $\mathbf{2 0 0 3}$ & Total \\
\cline { 2 - 9 } & $\begin{array}{l}\text { No of } \\
\text { Articles }\end{array}$ & $\begin{array}{l}\text { \% of } \\
\text { Period }\end{array}$ & $\begin{array}{l}\text { No of } \\
\text { Articles }\end{array}$ & $\begin{array}{l}\text { \% of } \\
\text { Period }\end{array}$ & $\begin{array}{l}\text { No of } \\
\text { Articles }\end{array}$ & $\begin{array}{l}\text { \% of } \\
\text { Period }\end{array}$ & $\begin{array}{l}\text { No of } \\
\text { Articles }\end{array}$ & $\begin{array}{l}\text { \% of } \\
\text { Sample }\end{array}$ \\
\hline Economic & 90 & 25.1 & 73 & 18.4 & 33 & 19.3 & 196 & 21.2 \\
\hline Behavioural & 114 & 31.8 & 153 & 38.5 & 76 & 44.4 & 343 & 37.0 \\
\hline Both & 34 & 9.5 & 28 & 7.1 & 9 & 5.3 & 7.1 & 7.7 \\
\hline Unclear & 120 & 33.5 & 143 & 36.0 & 53 & 31.0 & 316 & 34.1 \\
\hline Total & 358 & 100.0 & 397 & 100.0 & 171 & 100.0 & 926 & 100.0 \\
\hline
\end{tabular}

\section{CONCLUDING COMMENTS}

This paper has reported the first results of a project that aims to critically examine the nature and theoretical foundations of DSS research. Although the reported analysis is only descriptive it does throw some light on the issues and concerns that motivated the study. Amongst other findings, the analysis suggests that:

1. DSS research is focussed on three main application areas: personal DSS, group support systems, and large-scale data-driven systems. Personal DSS research is declining in influence while large-scale data-driven systems research is increasing.

2. DSS research is strongly dominated by empirical studies that adopt a positivist ontology and epistemology. The most popular research methods used in this group of papers are experiments, surveys, and descriptions of specific applications and systems. DSS research is more dominated by positivism than general IS research.

3. The assessment of the practical relevance of DSS research shows a discipline that is significantly distanced from professional practice.

4. The lack of identification of the nature of the primary clients/sponsors and the primary users of DSS is a major shortcoming of DSS scholarship.

5. Almost half of published DSS research is not grounded in judgement and decision-making research.

6. Prescriptive and behavioural approaches to decision-making are the most cited in DSS research.

7. The work of Herbert Simon is the most influential judgement and decision-making reference theory in DSS research.

These findings provide DSS researchers with a call for reflexion and reassessment of their discipline. It provides signposts for redefining research agendas to ensure that the discipline prospers. Without this reflexion and redirection we believe that DSS will be increasingly distanced from professional practice, contemporary reference research, and other sub-specializations of IS.

The next stage of the project will involve more sophisticated and complex data analyses, in particular, cross tabulations and correlation analysis. In addition to the descriptive statistics reported in this paper, the questions that we are interested in pursuing include:

- What research paradigms are dominant in the various types of DSS?

- What judgement and decision-making theories underlie the various DSS types?

- What are the organizational and development focuses of the different types of DSS?

- What types of DSS have the highest practical relevance? 
- Has the nature and amount of judgement \& decision-making research cited changed over time?

- What is the nature of DSS research published in the different journals?

- How is DSS research different to general IS research?

Further, we intend to investigate the nature of the financial support of high quality published DSS research. In particular we are interested in which styles of research and which types of DSS are supported by major competitive grants.

It is hoped that this program of research can help DSS researchers in understanding the trends in DSS research, suggest future research opportunities and improve the quality and relevance of their research. In particular, it is important for Australian researchers to focus more on data warehousing and business intelligence as these DSS types have had relatively little research attention but are central to current Australian IT investment.

\section{REFERENCES}

Alavi, M., \& Carlson, P. (1992). A review of MIS research and disciplinary development. Journal of Management Information Systems, Vol 8 (4), 45-62.

Alavi, M., \& Leidner, D.E. (2001). Review: Knowledge management and knowledge management systems: conceptual foundations and research issues. MIS Quarterly, Vol 25 (1), 107-136.

Alexander, E.R. (1979). The design of alternatives in organizational contexts: A pilot study. Administrative Science Quarterly, Vol 24, 382-404.

Alter, S. (1992). Why persist with DSS when the real issue is improving decision making? In T. Jelassi, H. Klein \& W.M. Mayon-White (Eds.), Decision support systems: Experiences and expectations (pp. 1-11). Amsterdam: Elsevier Science (North-Holland).

Angehrn, A.A., \& Jelassi, T. (1994). DSS research and practice in perspective. Decision Support Systems, Vol 12, 257-275.

Arnott, D.R., \& O’Donnell, P.A. (1994). Business process re-engineering and decision support systems: A cautionary tale. In B.C Glasson, I.T. Hawryszkiewycz, B.A. Underwood \& R. Weber (Eds.). Business process re-engineering: Information systems opportunities and challenges (pp. 127-135). Amsterdam: Elsevier North-Holland.

Arnott, D., Pervan, G., O’Donnell, P., \& Dodson, G. (2004). An analysis of decision support systems research: Preliminary results. In R. Meredith, G. Shanks, D. Arnott \& S. Carlsson (Eds.). Proceedings of the 2004 IFIP International Conference on Decision Support Systems (pp. 25-37). Prato, Italy:IFIP.

Bell, D.E., Raiffa, H., \& Tversky, A. (1988). Descriptive, normative and prescriptive interactions in decision making. In D.E. Bell, H. Raiffa \& A. Tversky (Eds.), Decision making: Descriptive, normative and prescriptive interactions (pp. 9-30). Cambridge, UK: Cambridge University Press.

Benbasat, I., \& Nault, B. (1990). An evaluation of empirical research in managerial support systems. Decision Support Systems, Vol 6, 203-226.

Benbasat, I., \& Zmud, R.W. (1999). Empirical research in information systems: The question of relevance. MIS Quarterly, Vol 23 (1), 3-16.

Bidgoli, H. (1998). Intelligent management support systems. Westport CT: Greenwood.

Carlsson, S., Brezillon, P., Humphreys, P., Lunberg, B.G. McCosh, A., \& Rajkovic, V. (Eds.) (2000). Proceedings of IFIP TC8/WG8.3 International Conference on Decision Support Through Knowledge Management. Stockholm, Sweden: Stockholm University/Royal Institute of Technology, Sweden.

Cavaye, A.L.M. (1996). Case study research: A multi-faceted research approach for IS. Information 
Systems Journal, Vol 6, 227-242.

Codd, E.F., Codd, S.B., \& Salley, C.T. (1993). Providing on-line analytical processing (OLAP) to user-analysts: An IT mandate (Unpublished Manuscript). E.F. Codd and Associates.

Dennis, A.R., George, J.F., Jessup, L.M., Nunamaker, J.F. Jr., \& Vogel, D.R. (1988). Information technology to support group meetings. MIS Quarterly, Vol 12 (4), 591-624.

Doukidis, G.I., Land, F., \& Miller, G. (1989). Knowledge based management support systems. Chichester: Eliis Horwood.

Elam, J.J., Javenpaa, S.L., \& Schade, D.A. (1992). Behavioural decision theory and DSS: New opportunities for collaborative research. In E.A. Stohr \& B.R. Konsynski (Eds.). Information systems and decision processes (pp. 51-74). Los Alamitos, CA: IEEE Computer Society Press.

Eom, H.B., \& Lee, S.M. (1990). A survey of decision support system applications (1971-1988). Interfaces, Vol 20, 65-79.

Fitzgerald, B. (2000). System development methodologies: The problem of tenses. Information Technology and People, Vol 13 (3), 13-22.

Galliers, R.D. (1992). Choosing information systems research approaches. In R.D. Galliers (Ed.), Information systems research: Issues, methods and practical guidelines (pp. 144-162). London: Blackwell Scientific.

Galliers, R.D. (1994). Relevance and rigour in information systems research: Some personal reflections on issues facing the information systems research community. In B.C Glasson, I.T. Hawryszkiewycz, B.A. Underwood \& R. Weber (Eds.). Business process reengineering: Information systems opportunities and challenges (pp. 93-101). Amsterdam: Elsevier North-Holland.

Gigerenzer, G. (2000). Adaptive thinking: Rationality in the real world. New York: Oxford University Press.

Goodwin, P., \& Wright, G. (1991). Decision analysis for management judgement. Chichester, UK: Wiley.

Gorry, G.A., \& Scott Morton, M.S. (1971). A framework for management information systems. Sloan Management Review, Vol 13 (1), 1-22.

Guba, E.G., \& Lincoln, Y.S. (1994). Competing paradigms in qualitative research. In N.K. Denzin \& Y.S. Lincoln (Eds.). Handbook of qualitative research (pp. 105-117). Thousand Oaks, CA: Sage Publications.

Hirschheim, R. (1992). Information systems epistemology: An historical perspective. In R. Galliers (Ed.), Information Systems Research: Issues, Methods and Practical Guidelines (pp. 2860). Oxford: Blackwell Scientific Publications.

Inmon, W., \& Hackathorn, R. (1994). Using the data warehouse. New York: John Wiley \& Sons.

Keen, P.G.W., \& Scott Morton, M.S. (1978). Decision support systems: An organisational perspective. Reading, MA: Addison-Wesley.

Kendall, K.E. (1997). The significance of information systems research on emerging technologies: seven information technologies that promise to improve managerial effectiveness. Decision Sciences, Vol 28 (4), 775-792.

Kimball, R., Reeves, L., Ross, M., \& Thornwaite, W. (1998). The data warehousing lifecycle toolkit. New York: John Wiley \& Sons.

Lipshitz, R., \& Bar-Ilan, O. (1996). How problems are solved: Reconsidering the phase theorem. Organizational Behavior and Human Decision Processes, Vol 65 (1), 48-60.

Malone, T.W., \& Crowston, K. (1994). The interdisciplinary study of coordination. ACM Computing Surveys, Vol 26 (1), 87-119.

McCosh, A.M., \& Scott Morton, M.S. (1978). Management decision support systems. London: 
Macmillan.

Orlikowski, W.J., \& Baroudi, J.J. (1991). Studying information technology in organizations: Research approaches and assumptions. Information Systems Research, Vol 2, 1-28.

Pervan, G.P. (1998). A review of research in group support systems: Leaders, approaches and directions. Decision Support Systems, Vol 23 (2), 149-159.

Pervan, G.P., \& Atkinson, D.J. (1995). GDSS research: An overview and historical analysis. Journal of Group Decision and Negotiation, Vol 4 (6), 475-485.

Poon, P., \& Wagner, C. (2001). Critical success factors revisited: Success and failure cases of information systems for senior executives. Decision Support Systems, Vol 30, 393-418.

Rangaswamy, A., \& Shell, G.R. (1997). Using computers to realize joint gains in negotiations: Toward an 'Electronic Bargaining Table'. Management Science, Vol 43 (8), 1147-1163.

Rockart J.F. and DeLong D.W., 1988. Executive Support Systems: The Emergence of Top Management Computer Use, Illinois: Dow Jones-Irwin.

Robey, D., Boudrea, M-C., \& Rose, G.M. (2000). Information technology and organizational learning: a review and assessment of research. Accounting, Management \& Information Technology, Vol 10, 125-155.

Saunders, C. (1998). The role of business in IS research. Information Resource Management Journal, Winter, 4-6.

Simon, H.A. (1956). Rational choice and the structure of the environment. Psychological Review, Vol 63, 129-138.

Simon, H.A. (1977). The new science of management decision (rev. ed.). Englewood Cliffs, NJ: Prentice-Hall.

Stohr, E.A., \& Konsynski, B.R. (Eds.). (1992). Information systems and decision processes. Los Alamitos, CA: IEEE Computer Society Press.

Walsham, G. (1995a). Interpretive case studies in IS research: Nature and method. European Journal of Information Systems, Vol 4, 74-81.

Walsham, G. (1995b). The emergence of interpretivism in IS research. Information Systems Research, Vol 6 (4), 376-394.

Webster, J., \& Watson, R.T. (2002). Analyzing the past to prepare for the future: Writing a literature review. MIS Quarterly, Vol 26 (2), xiii-xxiii.

Witte, E. (1972). Field research on complex decision making processes: The phase theorem. Management and Organization, Vol 2, 156-182. 